\title{
How overconfidence influences entrepreneurship
}

\author{
Ioannis S Salamouris
}

Correspondence:

isalamouris@hauniv.us

Hellenic American University, 22

Massalias Street, Athens 10680,

Greece

\begin{abstract}
The only thing certain in economic life is that most of it is conducted into an uncertain environment; that raises a question though: what makes individuals pursue entrepreneurship which engages too much risk for an unsure, or too little, return? Research has shown that people tend to be optimistic when a decision is made under uncertainty (Taylor and Brown, Psychological Bulletin, 103:193-210, 1988) and exhibit overconfidence in judgment (DeBondt and Thaler 1995). Overconfident individuals tend to overestimate their relative ability (Svenson, Acta Psychologica 47:143-148, 1981); therefore, their perception about their actions, probabilistically, appears to them to be safer than that of others who exhibit no overconfidence. A sample of 2,994 entrepreneurs provides us with interesting findings (Cooper et al., Journal of Business Venturing 3:97-108, 1988): 81\% consider their chances of success to be at least $70 \%$, and $33 \%$ believe their chances of success to reach a probability of $100 \%$. In reality, about $75 \%$ of new businesses no longer exist after 5 years. Is it that entrepreneurs are incapable of seeing the risk or/and measure it, or is it that they consciously perceive a different dimension of risk involved in their actions? A more recent study (Wu and Knott, Management Science 52:1315-1330, 2006) showed, in general, that entrepreneurs are more cautious than most of us would think or believe, and the belief that entrepreneurs have bigger tolerance for risk is rather unsupported according to their findings. Although there are some cases where entrepreneurs appear to be more risk averse than average, still it does not prevent them to bear risk. Such finding sounds controversial, but in reality it is not. Entrepreneurs seem to set different dimensions for uncertainty; thus, the oxymoron suggested above actually justifies their actions. Entrepreneurs believe that uncertainty has two dimensions: the market uncertainty and the uncertainty regarding ability. Similar to the majority of people, entrepreneurs detest the market risk but, on the other hand, they much appreciate their own abilities(overconfidence) that compensate for their dislike of risk. The purpose of this paper is to highlight the impact of overconfidence in entrepreneurial behavior.
\end{abstract}

Keywords: Entrepreneurship overconfidence, Uncertainty, Behavior

\section{Review}

Psychologists show that, mainly, people are overconfident about their abilities and about the precision of their knowledge (Fischhoff et al. 1977; Alpert and Raiffa 1982; Lichtenstein et al. 1982).

Overconfidence creates a state of mind where individuals underestimate possible dimensions of potential outcomes not because they do not assess them as important but rather because they overestimate their ability to deal with those when and if the time comes. Overconfidence has been documented in many cases and in various forms. 
Most of the evidence that exhibits overconfidence occurs from calibration studies. Subjects are presented with a series of general knowledge questions: for instance, which river is bigger, Amazon or Nile, or prediction problems, who will win the elections. In addition, the individuals were asked to assess the probability of their answer to be correct. In the majority of such studies (Taylor and Brown 1988;Svenson 1981), individuals assessed the probability of their answer to be correct as very high, though the outcome of their answers was not in accordance with the probability stated earlier. This finding clearly suggests that people perceive their knowledge to be more accurate than it really is and assess their ability better than average. Consequently, the element of overconfidence could be playing a vital role in the decision-making process. Similar results occurred even when individuals were asked to stake money on their answers, not exhibiting any change on their answers or the assessment of how accurate they think their answers are. Even in more extreme cases where individuals said that they were certain regarding the accuracy of their answers, only $80 \%$ were in fact correct. The overconfidence phenomenon persisted again. Even when individuals were exposed to the correct answers, still the level of their overconfidence was not affected. The question that arises is thus: do people not learn out of their mistakes and try to correct their overconfidence?

Clearly, people do learn when the consequences of their errors are frequently presented to them, and sometimes from being overconfident they become less confident. But in general, people tend to be biased toward overconfidence. Probably, a significant part of overconfidence is forgetting about contrary evidence or underestimating unfavorable results, considering them as unique or extreme cases.

The purpose of this paper is to highlight the importance of overconfidence in human behavior and emphasize how overconfidence is affecting entrepreneurial behavior in particular.

DeBondt and Thaler (1995) suggested that 'Perhaps the most robust finding in the psychology of judgment is that people are overconfident.' Overconfidence is the driving force that encourages individuals to take on ventures that other individuals might not undertake. Some might say that such decisions engage some level of irrationality, but recent studies have provided significant evidence why such an irrational behavior can, and most of the times do, persist.

In the last decade, work in economics and finance (e.g., Delong et al. (1991), Daniel et al. (1998), Odean (1998)) area suggested that overconfidence triggers a behavior that theoretically is irrational but practically is highly applicable. Numerous examples can be found in the behavior of investors and analysts in the stock market, where people exhibit irrational behavior just because they overestimate their ability or perceive that the probability of being wrong is very small. Griffin and Tversky (1992) stress that in cases where predictability is very limited, as in securities markets, experts may even be more inclined to overconfidence than novices. In other words, the uncertainty that evidently exists in a stock market may be compensated by a high level of overconfidence in order for a decision to be made. In theory, decisions should be made when information is sufficient. In practice though, when decisions should be taken and the information does not suffice, overconfidence steps in to rationalize a decision. 


\section{Overconfidence and entrepreneurs}

Overconfidence among entrepreneurs has been documented in the work of Cooper et al. (1988). More specifically in a sample of 2,994 entrepreneurs, $81 \%$ of them, approximately 2,450 , believe that their chances of success are at least $70 \%$. Of the sample, $33 \%$ believe in an absolute $100 \%$ chance of succeeding, while $75 \%$ of new businesses will fail shortly after inception or will not make it within the next 5 years.

Another research by Busenitz and Barney (1997) revealed that when entrepreneurs were asked a question related to whether cancer or heart disease is the leading cause of death in the USA, against other individuals, entrepreneurs present a level of confidence in their answers which was significantly higher than those of others while the number of correct results were equally dispersed.

Entrepreneurs frequently exhibit the tendency to underestimate the likelihood of unfavorable results to occur. The chances of a new venture to fail or the profit that a firm will earn, as also the reaction of the competition, have been underestimated because the entrepreneurs show overconfidence in their ability to prevent all unfavorable things to happen.

Palichand Bagby (1995) and Busenitz and Barney (1997) indicated that while the majority of managers are overconfident, entrepreneurs exhibited greater overconfidence than managers. This finding suggests that several launches of new ventures were the outcome of the overconfidence that entrepreneurs show. Equally, overconfidence could be to a degree responsible for the fairly high incidence of new venture failures, given that overconfident entrepreneurs are expected to overestimate their ability to make correct decisions in launching and developing their new businesses.

It follows that if entrepreneurs normally display overconfidence, also young entrepreneurs may possibly exhibit overconfidence when shaping their intention to start their own businesses.

Several studies (Douglas and Shepherd 2002; Fitzsimmons and Douglas 2005) suggested that the purpose to become self-employed has a high level of dependency on the individual's feelings to independence, ownership, and risk. In other words, because of their perceptions, individuals may be encouraged to proceed with a new venture. Hence, a question arises as to whether entrepreneurial intensions are affected independently by overconfidence or whether overconfidence operates as a moderator of these entrepreneurial intentions.

Both instances, in my belief, work complementarily. The sense of independence, ownership, and risk may be facilitated by becoming self-employed, while in not exhibiting confidence about your own ability to succeed, the attempt will fail.

The level of confidence that individuals exhibit will perform as long as it becomes a conscious belief. According to Forbes (2005), a distinction is made between overconfidence and self-efficacy. More specifically, Forbes clarifies overconfidence as a measure of accuracy of an individual's ability, while entrepreneurial self-efficacy measures the individual's perception of their abilities. Such distinction suggests that overconfidence becomes a subconscious phenomenon, whereas entrepreneurial self-efficacy evolves into a consciously held belief. In addition, Forbes (2005) claims that an individual's entrepreneurial self-efficacy varies to different levels of over-inflated opinions about their abilities. In such cases, the more over-inflated opinion, the higher the probability for individuals to demonstrate overconfidence in their abilities. Based on that, several 
entrepreneurs, with past business successes, will inevitably turn out to be more overconfident because their self-efficacy level is very high. Thus, overconfidence seems to act as an independent variable that holds the relationship between entrepreneurial selfefficacy and entrepreneurial intentions.

Overconfidence replaces lack of information by overestimating ability. Langer (1975) has observed that the more difficult the task, the greater the chance of overconfidence to kick in and increase. On top of that, individuals that successfully completed tasks in the past experience an increase in their confidence regardless if this confidence is justified or not. From a point onward, individuals tend to disregard the information or the risks associated to a task and are based solely on their over-inflated ability, which is built up on past incidents which might not have been always successful, Lichtenstein et al. 1977.

When entrepreneurs are overconfident, they exhibit the tendency to follow their own information, down-weighting the publicly available information or ignoring the complete lack of any information whatsoever. The rest of the individuals that observe such behavior tend to believe that entrepreneurs are fearless of risk or that they have a higher level of risk tolerance. Such perception existed for many years and mainly was considered to be one of the distinct characteristics of entrepreneurs. A study by $\mathrm{Wu}$ and Knott (2006) provided contrary information to that belief. More specifically, Wu and Knott (2006) observed that entrepreneurs are more cautious than most of us think. In several cases, entrepreneurs appeared to be more risk averse than the average, without though being discouraged in undertaking new ventures and obviously risk. Such a finding seems contradicting but actually is not. The explanation to that is based on the perception that entrepreneurs place to risk. The majority of individuals identify risk as the level of uncertainty of something to happen or not; therefore, the greater the uncertainty, the greater the risk. Entrepreneurs set different dimensions for uncertainty, which allow them to proceed with tasks, which for the majority of individuals appear very uncertain.

Entrepreneurs believe that uncertainty has two dimensions, one is the well-known market uncertainty (systemic risk) and the other is the uncertainty regarding ability. Like the majority of people, entrepreneurs dislike risk but, on the other hand, place great value on their ability. The appreciation of their ability comes in and compensates for the market risk; thus, any new venture becomes less risky and possibly more appealing.

Such findings imply that, as long as there is a great appreciation in the ability of the entrepreneurs, no venture is risky enough to discourage them. Conversely, if a high degree of uncertainty exists regarding ability, entrepreneurs will avoid entering in such ventures because their perceived lack of ability will never overcome the systemic risk.

It appears then that the volume of information which could reveal the level of uncertainty in a venture somehow becomes insignificant. Non-entrepreneurs try to be rational by supporting their decision not only on private but also on public information. Entrepreneurs do the same but place more weight on their own information which is the outcome of their ability and reduce the value of public information.

\section{Conclusions}

In this paper, it is argued that overconfidence is something that characterizes human behavior in most cases. People tend to appreciate their knowledge highly even in cases 
where prior experience is contrary to that. The literature suggests that such overconfidence is something to be expected and most probably in cases where little information is available, but the impact of overconfidence on people's behavior may differ depending on their perception about uncertainty.

Non-entrepreneurs exhibit overconfidence up to the limit on which the information is considered insufficient; therefore, the task in hand becomes uncertain. Entrepreneurs, on the other hand, exhibit similar overconfidence regardless of the available information. The driving force is the self-assessment of their skills and ability which appears to be unrelated to the level of information. Their ability is enough to compensate any lack of information. Clearly, when entrepreneurs over-assess their ability or believe that their ability will suffice to overcome objective difficulties, then the probability of failure increases significantly. Prior failures do not discourage them because part of overconfidence is isolating unfavorable results, thinking of them as out of the norm.

Entrepreneurs behave in a rational manner, contrary to what other individuals may think, under the influence of overconfidence which apparently characterizes human behavior. A question for further research that arises is when or under what circumstances is entrepreneurial ability not sufficient to overcome the risk in any new ventures.

Competing interests

The author declares that he has no competing interests.

Author's information

IS is an Assistant Professor of Finance at Hellenic American University (www.hauniv.us). In addition, IS is the Director of the Office of Institutional Research and Assessment (OIRA) of the University. IS is also the President of a Social Enterprise for Education and Lifelong Learning (www.knowl.gr). Last year, IS has become a Member of the Policy Committee of the Federation of Hellenic Associations of Young Entrepreneurs (http://www.esyne.gr).

Received: 20 November 2012 Accepted: 7 May 2013

Published: 27 May 2013

\section{References}

Alpert, M, \& Raiffa, H. (1982). A progress report on the training of probability assessors. In D Kahneman, P Slovic, \& A Tversky (Eds.), Judgment under uncertainty: heuristics and biases (pp. 294-305). Cambridge: Cambridge University Press.

Busenitz, LW, \& Barney, JB. (1997). Differences between entrepreneurs and managers in large organizations: biases and heuristics in strategic decision-making. Journal of Business Venturing, 12(1), 9-30.

Cooper, AC, Woo, CA, \& Dunkelberg, W. (1988). Entrepreneurs perceived chances for success. Journal of Business Venturing, 3, 97-108

Daniel, K, Hirshleifer, D, \& Subrahmanyam, A. (1998). A theory of overconfidence, self-attribution, and security market under- and over-reaction. Journal of Finance, 53(5), 1839-1886.

DeBondt, WFM, \& Thaler, RH. (1995). Financial decision-making in markets and firms: a behavioral perspective. In R Jarrow, V Maksimovic, \& W Ziemba (Eds.), Handbook in operations research and management science, Vol. 9, Chap. 13 (pp. 385-410). North Holland, Amsterdam: Finance, Elsevier.

Delong, BJ, Shleifer, A, Summers, L, \& Waldmann, RJ. (1991). The survival of noise traders in financial markets. Journal of Business, 64(1), 1-20.

Douglas, EJ, \& Shepherd, DA. (2002). Self-employment as a career choice: attitudes, entrepreneurial intentions, and utility maximization. Entrepreneurship Theory and Practice, Spring, 26, 81-90.

Fischhoff, B, Slovic, P, \& Lichtenstein, S. (1977). Knowing with certainty: the appropriateness of extreme confidence. Journal of Experimental Psychology. Human Perception and Performance, 3, 552-564.

Fitzsimmons, JR, \& Douglas, EJ. (2005). Entrepreneurial intentions: a cross-cultural study of potential entrepreneurs in India, China, Thailand and Australia. Paper presented at the Babson Kauffman entrepreneurial research conference. Wellesley. June 2005 .

Forbes, DP. (2005). Are some entrepreneurs more overconfident than others? Journal of Business Venturing, 20, 623-640.

Griffin, D, \& Tversky, A. (1992). The weighing of evidence and the determinants of confidence. Cognitive Psychology, 24(3), 411-435.

Langer, E. (1975). The illusion of control. Journal of Personality and Social Psychology, 32, 311-328.

Lichtenstein, S, \& Fischhoff, B. (1977). Do those who know more also know more about how much they know? Organizational Behavior and Human Performance, 20, 159-183.

Lichtenstein, S, Fischhoff, B, \& Phillips, L. (1982). Calibration of probabilities: the state of the Art to 1980. In D Kahneman, P Slovic, \& A Tversky (Eds.), Judgment under uncertainty: Heuristics and biases (pp. 306-334). Cambridge: Cambridge University Press. 
Odean, T. (1998). Volume, volatility, price, and profit when all traders are above average. Journal of Finance, 53(6), 1887-1934.

Palich, LE, \& Bagby, DR. (1995). Using cognitive theory to explain entrepreneurial risk-taking: challenging conventional wisdom. Journal of Business Venturing, 10(6), 405-417.

Svenson, O. (1981). Are we all less risky and more skillful than our fellow drivers? Acta Psychologica, 47, 143-148.

Taylor, SE, \& Brown, JD. (1988). Illusion and well-being. A social psychological perspective on mental health. Psychological Bulletin, 103, 193-210.

Wu, B, \& Knott, AM. (2006). Entrepreneurial risk and market entry. Management Science, 52(9), 1315-1330.

doi:10.1186/2192-5372-2-8

Cite this article as: Salamouris: How overconfidence influences entrepreneurship. Journal of Innovation and Entrepreneurship 2013 2:8.

Submit your manuscript to a SpringerOpen ${ }^{\circ}$ journal and benefit from:

- Convenient online submission

- Rigorous peer review

- Immediate publication on acceptance

- Open access: articles freely available online

- High visibility within the field

- Retaining the copyright to your article

Submit your next manuscript at $\gg$ springeropen.com 